\title{
ARTIKEL \\ PERSUASIVE TECHNIQUE OF COMMERCIAL ADVERTISEMENTS \\ ON BILLBOARD IN MEDAN
}

Disusun dan Diajukan oleh:

Reza Saputra Rambe

NIM. 2123220030

Telah diverifikasi dan dinyatakan memenuhi syarat untuk diunggah pada jurnal online

Medan, Juni 2017

Menyetujui

Dosen Pembimbing Skripsi I

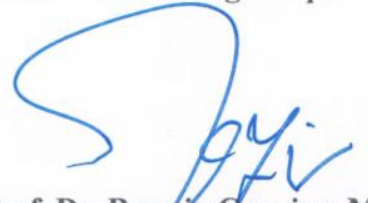

Prof. Dr. Busnum Curning, M.Pd.

NIP. 195907131986011001
Dosen Pembimbing Skripsi II

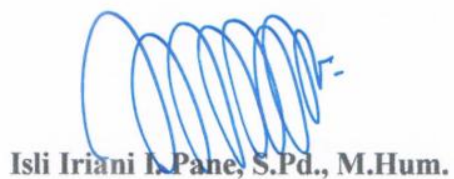

NIP. 197908022005012003

Ka. Program Studi

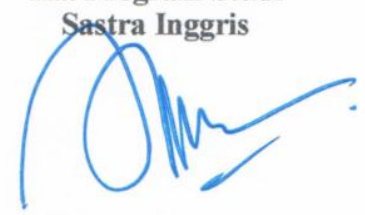

Juli Rachmadani Hasibuan, S.S., M.Hum.

NIP. 198207112008012008 


\title{
PERSUASIVE TECHNIQUE OF COMMERCIAL
}

\section{ADVERTISEMENTS ON BILLBOARD IN MEDAN}

\author{
*Reza Saputra Rambe \\ **Prof. Dr. Busmin Gurning, M.Pd \\ **Isli Iriani Indiah Pane, S.Pd., M.Hum
}

\begin{abstract}
Rambe, Reza Saputra. 2123220030. Persuasive Technique of Commercial Advertisements on Billboard in Medan. A Thesis. Faculty of Languages and Arts. State University of Medan. 2017.

This study deals with Persuasive Technique of Commercial Advertisement on Billboard in Medan. This study is aimed at analyzing: (1) persuasive technique applied in the commercial advertisement on billboard in Medan, and (2) the reason of using the persuasive technique in the billboard commercial advertisement. It employs descriptive qualitative research method to conduct this study with. The data of this study are pictures and writings in 33 the commercial advertisements which were displayed at Jl. Gatot Subroto and Jl. Gadjah Mada, Medan. The data is analyzed by using the theories from Keraf (1991) about the persuasive techniques. There are seven techniques were applied in the billboard commercial advertisements, they are Rationalization (10 of 33 advertisements), Identification (13 of 33 advertisements), Suggestion (20 of 33 advertisements), Conformity (7 of 33 advertisements), Compensation (9 of 33 advertisements), Displacement (1 of 33 advertisements), and Projection (7 of 33 advertisements). One advertisement could use more than one persuasive techniques. Furthermore, the reason why the persuaders applied the persuasive techniques is to make their readers believed what they said and wanted to buy and consume the products.
\end{abstract}

Keywords: persuasion, persuasive techniques, commercial advertisement, billboard.

*Graduate Status
**Lecturer Status 


\section{INTRODUCTION}

\section{Background of the Study}

In communication, people do not only express their feelings, arguments or ideas but also influence other people. Influence can be related to persuasion. Persuasion is defined as human communication design to influence others by modifying their beliefs, values and attitudes. In doing the persuasion, the persuader will needs the language to persuade others so that they can interpret and follow the message.

Persuasion can be said as a part of Discourse Analysis which is a strategy to try creating a particular effect that is used purposefully (Daymon and Holloway, 2002: 140). It concerns with the language used for communication and how addressee worked in linguistic message in order to interpret them (Brown \& Yule, 1983:1). The goal of persuasion is to convince the readers' target, to believe the message and to do something as the result. Persuasion is also used in the area of advertising. The discourse of advertisement is a persuasive discourse when it is viewed in terms of content and purpose. Persuasive discourse is any writing in which an author is expressing facts or opinions to convince the readers.

In reality, the sentence which is written in the advertisement especially for cigarette advertisement does not interest, influence or even persuade the readers to consume the product but it is more likely to prohibition like "merokok membunuhmu". This is contrary to the purpose of advertisement itself which persuades the readers to buy the product. The use of language whose the meaning is not in accordance with the advertisement offered, for example, the billboard 
advertisement of cigarette : "Pikir Pendek. Go Ahead". Here, there is no relevant between the meaning of language and the promoted product.

In fact, the advertisers do not only use language to persuade the people, but they also display the picture as technique of persuasion in the advertisement. The advertisers display the picture to attract the readers' attention. The advertisers also hire the popular person like athlete, actor or actrees to easily make the readers interested in product which is being promoted. The opinion of people who has used the promoted product can be applied by the advertisers as technique to convince the readers so that they can trust the benefits of the product.

The technique of persuasion in advertisement is used to persuade consumer, so people will give their attention to the products or service and will be interested to consume it. Advertisement is a form of using persuasive techniques which is presented attractively. According to Keraf, techniques of persuasion are rationalization, identification, suggestion, conformity, compensation, projection, and displacement (1991:124-131).

Advertisement can be in the printed form which appeals only to the sense of sight that is eyes, like newspaper, journal, magazines, billboard, etc. Billboard is a large outdoor advertising structure, typically found in high-traffic areas such as alongside busy roads, presents large advertisements to passing pedestrians and drivers. Billboard advertisements are designed to catch a person's attention and create a memorable impression very quickly, leaving the reader thinking about the advertisement. 
The language used in advertisement must be suitable with the consumers. Ogilvy in Boubehrezh and Iraji (2013:267) argues that "if you try to persuade people to do something or to buy something, it seems to me that you should use their language." Besides, the language of advertisement contains illustration and special power to persuade and to control the consumers' behavior. The use of language and the word choice become very important in advertising a product to attract the readers' attention.

The writer is interested in conducting this study, because the choice of words are unique in promoting the products. The use of those unique words in the advertisement is very helpful so that the readers can recognize the product which is being promoted and stimulate the readers' interest to know more information about the product, for instances the word "roso" in energy drink advertisement, "wani piro" in cigarette advertisement, "duobelicious" in food advertisement. The writer is also interested in knowing the persuasion techniques which are applied in the billboard with the limited use of word so that the words must be effective and also attractive to be viewed and read by people who see the advertisement.

This study deals with persuasive technique which is used in billboard especially for commercial advertisement. The commercial billboard advertisements which are displayed in Medan is going to be selected as the data of this study. The writer is interested to analyze persuasion techniques which are used in the billboard commercial advertisements 


\section{REVIEW OF LITERATURE}

\section{Discourse Analysis}

The analysis of discourse is necessarily the analysis of language in use. Then, Discourse analysis is committed an investigation of what and how that language is used for (Brown and Yule, 1983:1). It means that language is used for communicaton and it can be written or spoken form. Discourse analysis is fundamentally concerned with the general principles of interpretation by the people to make sense of what they hear and read.

In addition, Kinneavy (2014:301-303) stated that there are four main types of discourse, namely:

a. Expressive discourse, a type of discourse in which language is used as a simple vehicle for expression of some personality's aspect by the encoder (the person who encodes the message). On the oher hand, It focuses on the identity and/or the experience of the writer or speaker. Expressive discourse can be found in the conversation, journals, diaries.

$b$. Referential discourse, a type of discourse in which the use of language stresses the ability of language to designate or reproduce reality, in a manner of speaking. It can be found in the dialogues, seminars, articles, textbooks.

c. Literary discourse, a type of discourse in which the text or the product or the work itself is the focus of the process as worthy of being appreciated in its own right. Literary discourse can be found in the short story, lyric, drama, movie, joke. 
d. Persuasive discourse. A type of discourse which focused primarily on the decoder that is the other person involved in the process or the receiver of the message. In this type, what essential is the encoder, reality, and language itself all become instrument of the achievement of some practical effects in the decoder. Persuasive discourse can be found in the advertising, the political speeches, and the religious sermons.

From the explanation above, it can be concluded that Discourse Analysis is concerned with the language which is used for communication and how the receiver understands about the message. However, advertisement is an example of persuasive discourse where the language is used to influence and change attitude, belief, opinion, and take action.

\section{Persuasion}

Persuasion is a ubiquitous part of contemporary life. Persuasion is a process that change attitude, beliefs, opinion, or behaviour. In that definition the process of persuasion gets attention from the receiver. In line with that, Keraf (1991:118) argued that persuasion is the verbal art which aims to believe someone to do something that is desired by the speaker at this time or in the future. Persuasion does not use any form of force or violence against persons who receive persuasion. While Perloff defined persuasion as a symbolic process in which communicators try to convince other people to change their attitudes or behavior regarding an issue through the transmission of a message, in an atmosphere of free choice (2008:8). 
Persuasion is the communicative act that carries out two goals, to be understood and to be believed (Tailard, 2013). People must use the appropriate language to make the audience understand with the case that is going to discuss. Then, another goal is to be believed. It means people try to affect other people's beliefs, desires and actions. Shortly, the audience that has been persuaded has understood an utterance, and believed its message. The persuasive message should consist of a clearly uttered main issue and the ideas supporting it. It should be rational and logical, it should be emotional and it should give evidence, and it should consist of logical statements.

\section{Techniques of Persuasion}

The technique of persuasion is very essential in persuasion process to make people is influenced towards what the communicator said. Keraf (1991: 124-131) argues that techniques of persuasion are rationalization, identification, suggestion, conformity, compensation, displacement, and projection.

\section{a. Rationalization}

It is the use of mind process to give a justification for a certain problem. In this technique, the presenter or the advertiser needs only some statements as the proof to justify the product's quality and to give this justification. This technique provide the truth as the basic to influence people so that they can believe what the persuaser said. Although the truth which is said can be accepted by readers consciously and it is logic, bu it has not been absolute yet.

Technique of rationalization means a technique that can be used to influence others that what is said or done was right. The advertiser should know 
the audience's or consumer's needs, their attitude and belief. In persuading consumer, the advertiser gives some rationalizations. For example, "a man should not be afraid to dry his face exposed to the sun because it can be overcome with "Ponds Men". It means that "Ponds Men" is a solution for men to refresh their face.

\section{b. Identification}

In this technique, the advertisers have to analyze their readers or viewers or consumers and the situation accurately to avoid conflict situations and hesitant attitude. In other words, identification can mean to whom the advertisement were addressed. This technique make it easier for advertisers to promote the products that are sold in accordance with the criteria of potential buyers.

Attendees can consist of men, women, or both; or consisting of parents, youth, etc. By identifying the readers or viewers, the advertisers will be able to show their product to the consumer easily. For example, "the advertising of baby diapers, the consumers are the parents who have a baby, not the baby although the product is used for baby.

\section{c. Suggestion}

Suggestion is an effort to persuade or influence people to accept the certain conviction without giving a principle or logical belief to the persuaded people. Suggestion can run smoothly if the advertisers have the ability to master the language of advertising. The persuader usually will give suggestion by words and intonation. 
The series of words that are attractive and convincing, with a tone full of dignity can allow the audience will be affected. The sentence which is used is about giving the advice to the audience or solution of certain problem. The process of suggestion, however, such as direction that involves getting the consumer to accept the product without thinking an idea, belief or action. For example, "in the beauty advertisements, the words which are used such as "as a woman, self-care is very needed".

\section{d. Conformity}

Conformity is a desire or an action to make something similar with something else. In advertisement, it is a way of thinking to adapt or adjust the advertiser with the consumer's condition. It involves attitude that taken by the advertiser to adapt him with the condition (circumstances) or to do action for not arising strained situation. Conformity is usually also considered as an action that will bring positive influence up to progress.

In conformity, the advertiser will show that he is capable of doing and acting as the audience. For example, " the advertisers hire the famous soccer player in advertising their products, such as" football players from the Barcelona club also uses "Advan".

\section{e. Compensation}

It is an action or a result from an effort to look for a substitute for something unacceptable or indefensible circumstance. In persuasion, the presenters can push the consumers to do an action that is wanted by the presenters by convincing them that they have ability to do what the presenters' done. For 
example, in the cigarette advertisement, the advertisers replace the product is being promoted with another thing such as food.

\section{f. Displacement}

Displacement is a process that attempts displacing an intention or a matter that faces obstacles with the certain purpose or intention which also displaces the emotion of original hatred or sometimes the emotion of original affection at the same time. In this persuasion technique, the advertisers will try to convince the audience to divert an object or a particular purpose to another purpose. In this technique, the advertiser use the usual language or the language that is still acceptable to the public in order to displace rude language or the language that can discriminate one group.

\section{g. Projection}

It is a technique to make subject become the object. If someone is asked to describe somebody whom he hates, he will try to describe a good thing from himself. A mistake that is done by somebody shifted the mistake to other people, and said that he has it. So, projection is a technique which presents the advantages and disadvantages of the product to show the differences with other.

In this technique, the advertiser will make the actors in the advertising becomes the object who is seen by consumers. The advantages which are mentioned in the advertisement as the reflection of another product's disadvantages. For example, the woman in the beauty advertisement is as an agent but will be seen as an object by viewers, and said "after I use shampoo "Pantene", harifall and dandruff has gone. Bye-bye hairfall". 


\section{RESEARCH METHOD}

This study was conducted by descriptive qualitative method. Qualitative inquiry seek to interpret human actions in situations, events, customs, and the like and in doing construct a "reading" or portrayal, of what is being studied. The ultimate goal of this kind of inquiry is to portray the complex pattern of what is being studied in sufficient depth and detail so that someone who has not experienced it can understand it (Ary et al, 2002:423). The advertisements which became the source of data is only commercial advertisement on billboard in Medan. The data were the writings and the pictures in billboard advertisement which was exhibited in Medan. The data was taken from billboards that placed at the two main streets in Medan city, that are Jl. Gatot Subroto and Jl. Gajah Mada.

After the data were collected, they were analyzed by using some procedures as follows:

1. Identifying the sentences and pictures in the commercial advertisements on billboard which contained the persuasive techniques.

2. Classifying the types of persuasive techniques used in commercial advertisements on billboard.

3. Tabulating the data analysis of persuasive techniques and language style in commercial advertisements on billboard.

4. Interpretting the data analysis of persuasive techniques in commercial advertisements on billboard and explaining the reason of the use of persuasive technique.

5. Describing the conclusion based on the result of analysis. 


\section{RESULT AND DISCUSSION}

\section{Result}

After analyzing the colleted data, it was found that there were 33 billboard commerial advertisements which applied the persuasian techniques. It could be known by analyzing the pictures and the writings in the billboard advertisements. There were 84 writings were used in persuading the viewers and the readers. Language and pictures were used by the advertiser in promoting the product to persuade the readers. The techniques of persuasion are rationalization, identification, suggestion, conformity, compensation, displacement, and projection.

Table 1. Types of Persuasion Techniques used in Billboard Commercial Advertisement

\begin{tabular}{|c|c|c|}
\hline No. & $\begin{array}{c}\text { Types of Persuasion } \\
\text { Techniques }\end{array}$ & $\begin{array}{c}\text { Amount of } \\
\text { Advertisements (of 33) }\end{array}$ \\
\hline 1. & Rationalization & 10 \\
\hline 2. & Identification & 13 \\
\hline 3. & Suggestion & 20 \\
\hline 4. & Conformity & 7 \\
\hline 5. & Compensation & 9 \\
\hline 6. & Displacement & 7 \\
\hline 7. & Projection & 7 \\
\hline
\end{tabular}

Table 1 shows that there are seven techniques of persuasion applied in advertising the product on billboard. Based on the table above, Suggestion is the most often used persuasion technique where 20 of 33 advertisements use this 
technique. then it is follwed by Identification (13 of 33 advertisements), Rationalization (10 of 33 advertisement), Compensation (9 of 33 advertisements), Coformity and Projection (7 of 33 advertisements), and the last is Displacement (1 of 33 advertisement). It showed that one commercial billboard advertisement could apply more than one technique. Persuasion is an effort to convey information by means analyzing and understanding the public or audience accurately. Mostly, the advertisers applied the combination of some persuasion techniques in promoting their products to attrack the readers' attention and finally they will be persuaded to consume the product.

The persuasion techniques were applied in the billboard commercial advertisement to persuade the readers to look at, read, and finally want to buy the product which is offered, then consume it. The advertisers influenced their readers by pictures and writings so that they believe what the advertisers had written in the adverisements is true or logic. The advertisers could identify the use of picture and writings based on their target readers so that makes the process of persuading be easier and quicker. By applying the persuasion techniques, it helps the advertisers to make their advertisement be more interesting so that people want to look, read their advertisements and people will be persuaded to consume the product. The persuasion techniques were also used to make the process of persuading could run smoothly without any obstacles. On the other hand, the advertisements which were displayed can be accepted by all people and do not cause the conflict or even discriminate a certain group. 


\section{Discussion}

Keraf (1991 : 119) stated that persuasion aims to change the people's minds; the speaker tries to make people can accept and do anything like the speaker wants". The application of the persuasion techniques is very needed in order to convince the readers, change their mindset, make them believe and want to buy the product. One commercial Advertisement can use more than one persuasion techniques. The more techniques of persuasion are used, it can impact more opportunities the reader will buy and consume the product which is being advertised.

O’Shaughnessy (2004 : 33) stated that pictures can indeed more persuasive than a thousand words. Visual evidence is common in commercial advertising to show the effects of consuming the products. In the billboard advertisement, the advertiser display more pictures in promoting the products to catch the readers' attention from certain distance and make the readers interested to read the advertisement. Visual evidence is used to influence and convince the readers to believe what is displayed in the advertisement.

Kitis (1997 : 304) argues that advertising is a discourse that epitomizes "powerful" language. The advertiser prooted and informed the product by using language. In this study, there are some new words found in promoting the product like Duobelicious. It is blend words from "double" and "delicious". The advertiser created that word as the jargon of the product. Another sentences like I AM BOLD and Everyone got the BEAT, the word "Bold" and "Beat" refered to the name of the product. 


\title{
CONCLUSION AND SUGGESTION
}

\author{
Conclusion
}

After analyzing the data which regarded to the persuasive technique applied in billboard commercial advertisements, finally the writer went to the conclusions that presented as follows.

There are seven techniques of persuasion which were applied in the commercial advertisement on billboard. They are rationalization, identification, suggestion, conformity, compensation, displacement, and projection. The persuasion technique which is the most often used is suggestion technique. One advertisement applied one persuasion technique at least and could be more than one persuasion technique. In billboard advertisement, the advertisers use the picture to promote their products in the public places. The pictures and the writings in the advertisement are used as the techniques to persuade people.

The advertisers used the persuasion technique to influence the readers or viewers so that they are interested in reading, believe what is presented about the advertised product, then they want to buy the product consciously and use it without any coercion or discrimination from anybody. The persuasion techniques help the advertisers to promote their products in the public place to avoid the obstacles, so that the advertisement can be accepted by anyone. The advertisements can be more interesting to attrack the readers' sight. 


\section{Suggestion}

There are several suggestions that can be offered based on the analysis of the study, they are:

1. The writer suggests the readers of the advertisement not to easily trust the information which has been delivered in the advertisement because some advertisements exaggerated when promoting the product.

2. This study can be review for the next researchers who want to analyze about persuasive technique in different point of view. The writer suggests to use the other object such as electronic advertisement.

3. For the advertisers, they can use the pictures which contain of Indonesian's cultures or even tourism object in promoting their product so the readers can know more about Indonesia besides the main purpose is persuading the readers to buy and consume the product which is being advertised. 


\section{REFERENCES}

Ary, D, et al. 2002. Introduction to Research in Education (sixth edition). Belmont, California: Wadsworth/Thomson Learning.

Boubehrezh, S and Iraji, Maryam. 2013. The Study of Persuasion Language in Life Insurance Advertisements: International Reseach Journal of Applied and Basic Sciences, 6(2), 267-270.

Brown, G and Yule, G. 1983. "Discourse Analysis". Cambridge: Cambridge University Press.

Budiani, Y.S. 2014. An Analysis of Persuasive Techniques used in Cosmetics Advertisements. S1 Thesis. The State Islamic University of Sunan Ampel of Surabaya.

Daymon, C and Holloway, I. 2002. Qualitative Research Methods in Public Relations and Marketing Communications. London: Rouledge.

Cahyani, D.L. 2014. A Discourse Analysis on persuasion tehnique used in Smartfren advertisement. S1 Thesis. The State Islamic University of Sunan Ampel of Surabaya.

Gee, J.P. 2011. An Introduction to Discourse Analysis. New York : Rouledge.

Ghaemi, F and Sabokrouh, F. 2015. Discourse of Persuasion : An Analysis of Iranian Newspaper Advertisements. ICT \& Innovations in EducationInternational Electronic Journal, 3 (2), 1-12.

Grideanu, N. 2014. Advertisng Management. Review of General Management, 19 (1), 95-105.

Halliday, M. A. K. 2002. Linguistic Studies of Text and Discourse. London: Continuum (edited by Jonathan J. Webster).

Kenechukwu, S.A., et. al. 2013. Behind Advertising: The Language of Persuasion. International Jounal of Asian Social Science, 3 (4), 951-959.

Keraf, G. 1991. Argumentasi dan Narasi. Jakarta: Gramedia Pustaka Utama.

Keraf, G. 2001. Diksi dan Gaya Bahasa. Jakarta : Gramedia Pustaka Utama.

Kinneavy, J. E. 2014.The Basic Aims of Discourse. National Council of Teachers of English, 20 (5), 297-304. 
Kitis, E. 1997. Ads-Part of Our Lives: Lingusitic Awareness of Powerful Advertising. Words and Image, 13 (3), 304-313.

Maalej, Z. 2015. Research Gate. Persuasion in the Discourse of Billboards: A Stylistic Account, 1-16.

Metsämäki, M. 2012. Persuasive Discourse in EFL Debate. Theory and Practice in Language Studies, 2 (2), 205-213.

O'Shaughnessy, J and O'Shaughnessy, N. J. 2004. Persuasion in Advertising. London: Routledge.

Perloff, R. M. 2003. The Dynamics of Persuasion: Communication and Attitudes in The 21st Century. New Jersey: Lawrence Erlbaum Associates.

Sapriyani, D., et. al. 2013. Analysis of Language Style Found in Novel The Last Tycoon Written by F. Scott Fitzgerald. English Language and Litearature, 58-66.

Saragih, A. 2014. Discourse Analysis: A Study on Discourse Based on Systemic Functional Linguistic Theory. Medan: Unimed Press.

Sparks, J. R and Areni, C. S. 2008. Style Versus Substance: Multiple Roles of Language Power in Persuasion. Journal of Applied Social Psychology, 38 (1), 37-60.

Taillard, M.O. "Persuasive Communication: Case of Marekting". StudyMode.com. Retrieved 02, 2013, from http://www.studymode.com/essays/Persuasive-Communication-Case-OfMarekting-1448573.html

Ulumiyah, U.L. 2015. Persuasive Techniques used in Advertisement of "Colours" Magazine. S1 Thesis. The State Islamic University of Sunan Ampel of Surabaya.

Welukar, R and Harichandan, D. 2011. Advertising. Mumbai : University of Mumbai. 